\section{Integrated Pest Management and Biological Control in High Tunnel Production}

\author{
Laura Pickett Pottorff ${ }^{1,2}$ and Karen L. Panter ${ }^{3,4}$
}

ADDITIONAL INDEX WORDs. disease control, pests, insects, IPM

Summary. Crops grown in high tunnels are just as susceptible to pests and diseases as those grown under greenhouse and field conditions. Crops that lend themselves economically to this type of production system are edible and/or minor crops. Therefore, labeled pesticides for these crops are limited and sometimes nonexistent. However, there is a wide range of integrated pest management (IPM) strategies available to high tunnel producers. These strategies include biological control, which is often left out of traditional IPM programs when labeled pesticides are available. High tunnel production is very conducive to the inclusion of biological controls and allows for a truly IPM system. This article provides a selective overview of common arthropod pests and diseases encountered in high tunnels, as well as strategies that have potential for becoming best management practices in high tunnels with additional research.

$\mathrm{I}$ ntegrated pest management (IPM) is an approach to managing pests that uses appropriate physical, cultural, biological, and chemical tactics that are safe, profitable, and environmentally compatible (Thomas and Rajotte, 2004). Currently, literature on the efficacy of IPM and biological control in high tunnels is limited. This article provides a selective overview of IPM measures that have proven efficacious in greenhouse and high tunnel production, or are likely to perform well in high tunnels.

Like any sound pest and disease management system, IPM begins with prevention. The soil one plants in and the transplants one may bring into a high tunnel must be pest and disease free. Introducing pests and diseases into the high tunnel, or planting in disease- or insect-infested soil should be avoided. To minimize the buildup of soilborne pathogens, appropriate crop rotations should be practiced. Alternatively, if soil is infested with pathogens, soil solarization can be used, especially in warm, sunny climates. Soil solarization, as described by Katan et al. (1987), uses the sun's radiant energy to heat up

${ }^{1}$ Former Diagnostic Plant Pathologist and Regional Greenhouse Specialist, Colorado State University Extension, Adams County 9755 Henderson Road, Brighton, CO 80601

${ }^{2}$ Pesticide Applicator Coordinator, Colorado Department of Agriculture, 700 Kipling Street, Suite 4000 Lakewood, CO 80215

${ }^{3}$ Extension Horticulture Specialist, Plant SciencesDepartment 3354, University of Wyoming, 1000 East University Avenue, Laramie, WY 82071

${ }^{4}$ Corresponding author. E-mail: kpanter@uwyo.edu. the soil, controlling soilborne diseases and pests. Clear plastic sheets are placed on the soil during periods of high ambient temperature. In the western United States, solarization is most effective when soil is treated from June through August for a period of 4 to 6 weeks (Ellmore et al., 1997).

Soilborne diseases caused by Pythium, Fusarium, and Rhizoctonia do occur in high tunnels (Zitter, 2008) and are best handled preventively, as suggested in the previous paragraph. If extra protection against these pathogens is desired, consider establishing transplants and seeded crops in soil that has been pretreated with biofungicides (McSpadden Gardener and Fravel, 2002) or other types of bioantagonists. Many of these products are available commercially and involve artificially introducing microflora, usually beneficial fungi or bacteria, into the soil environment to prevent attack or to control a pathogen or pest. Many of these products are labeled to help prevent soilborne root rots caused by the pathogens Pythium, Fusarium, and Rhizoctonia (Table 1). While not as efficacious as synthetic fungicides in some cases, biofungicides may be combined with other management strategies to provide adequate control in many production systems (Shishkoff and McGrath, 2002).

Ensure that transplants produced in greenhouses are free of fungus gnat (Bradysia spp.) and shore fly (Scatella stagnalis) pests. Growers have reported bringing these pests in on plugs purchased from greenhouse suppliers (Moore, 2007). To protect transplants from fungus gnat and shore fly infestations, the predatory mite Hypoaspsis miles is one of the best biological control agents on the market and is a recommended management tool for these persistent pests. Hypoaspsis miles can also be used in conjunction with beneficial nematodes such as Steinernema spp.

Excluding pests and diseases from a crop is a very efficient mechanism for pest management. Screening from ground to ground with various types of mesh sizes can help keep out many different insect and mite pests (Bethke and Paine, 1991; Bethke et al., 1994). In Colorado, several covering types, including single-layer polyethylene, have been used for the purpose of excluding pests from high tunnels (Fig. 1). In 2007, the LS Econet B aphid screening (Gintec Shade Technologies, Birmingham, AL) was used with success to exclude flea beetle (Epitrix spp.) from ornamental and cruciferous plants. Flea beetle populations were much lower and plant quality was much higher in screened high tunnels versus roll-up sided high tunnels. In trials performed at the Colorado State University Horticulture Research Farm in Fort Collins in July 2006 (F. Stonaker, personal communication), screening increased temperatures as much as 2 to $4{ }^{\circ} \mathrm{F}$ when compared with ambient air temperatures. However, temperature within screened high tunnels using Tuffbell brand (ground to ground; G\&M Agricultural Supply, Payson, AZ) was not significantly different compared with the control (polyethylene with rolledup sides). An additional benefit of screens is reflective properties that serve to repel certain insects such as western flower thrips (Frankliniella

\begin{tabular}{llll}
\hline $\begin{array}{l}\text { Units } \\
\begin{array}{l}\text { To convert U.S. to SI, } \\
\text { multiply by }\end{array}\end{array}$ & U.S. unit & SI unit & $\begin{array}{l}\text { To convert SI to U.S., } \\
\text { multiply by }\end{array}$ \\
\hline$\left({ }^{\circ} \mathrm{F}-32\right) \div 1.8$ & ${ }^{\circ} \mathrm{F}$ & ${ }^{\circ} \mathrm{C}$ & $\left(1.8 \times{ }^{\circ} \mathrm{C}\right)+32$
\end{tabular}


Table 1. Examples of commercially available biofungicides and the fungi they are labeled to control (McSpadden Gardener and Fravel, 2002).

\begin{tabular}{ll}
\hline Biofungicide & \multicolumn{1}{c}{ Fungi controlled } \\
\hline Coniothyrium minitans & Sclerotinia \\
Streptomyces griseoviridis & Fusarium, Botrytis, Pythium \\
Trichoderma harzianum & Botrytis, Pythium, Rhizoctonia, Fusarium \\
Gliocladium virens & Pythium, Rhizoctonia, Fusarium \\
Bacillus subtillis & Pythium, Rhizoctonia, \\
& Fusarium, powdery mildew \\
& (Erysiphe, Sphaerotheca, Phyllactinia, etc.) \\
Burkholderia cepacia & Pythium, Rhizoctonia, Fusarium \\
Erwinia amylovora & Erwinia amylovora \\
HpN harpin protein & \\
Ampelomyces quisqualis & Powdery mildew \\
\hline
\end{tabular}
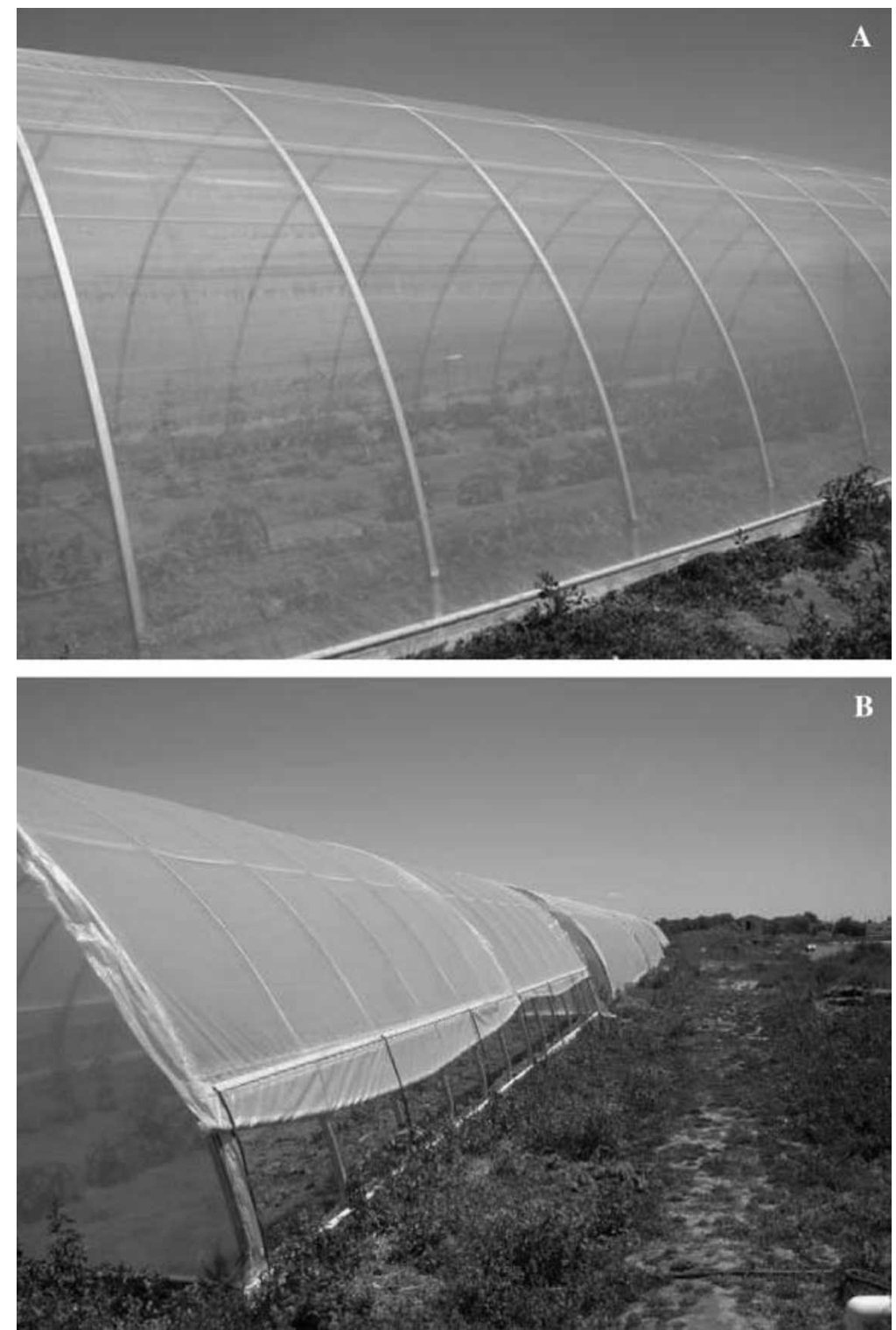

Fig. 1. High tunnel with LS Econet B ground-to-ground screening (Gintec Shade Technologies, Birmingham, AL) (A) and traditional poly-covered high tunnel (B) at the Colorado State University Horticulture Research Farm in Fort Collins. occidentalis) (Antignus, 2000). Growers should be aware that exclusion techniques may keep pollinators out of the high tunnel as well. This may be problematic with insect-pollinated crops.

When pests and diseases enter the high tunnel environment, there are many strategies that can be employed to manage them. Most are dependent upon the pest and crop. Below are some of the common pests encountered in high tunnels and suggested integrated strategies to consider in addition to the prevention and exclusion techniques listed above.

Western flower thrips are of particular concern to growers in all areas of the Unites States. This pest not only causes feeding injury to flowers and foliage, but it also is a potential vector of tospoviruses such as tomato spotted wilt and impatiens necrotic spot viruses (Figs. 2 and 3 ). These two viruses can affect over 500 different vegetable and ornamental plants (Smith, 2003).

If virus-vectoring thrips such as western flower thrips are of concern, tolerance of this pest is too low to allow for the use of biological control. To manage virus-vectoring thrips, the following IPM strategies are suggested: screening for exclusion, reflective mulches or screens to repel (Antignus, 2000), and insecticides such as spinosad (Greer and Diver, 1999).

If virus is not a concern, then the addition of biological control to manage thrips is possible. Two predators are commonly used with good success (Gill and Sanderson, 1998; Greer and Diver, 1999). These include the predatory mite Amblyseius cucumeris (Bessin et al., 1993) and the predatory bug Orius spp. (Weeden et al., 2002). Because $A$. cucumeris needs humidity levels above $65 \%$ to thrive, Orius spp. is preferred in arid environments. Natural populations of Orius spp. can be attracted by planting sunflower (Helianthus annuus) in proximity to high tunnels.

Psyllids (Bactericerca cockerelli) are insects that induce a toxemia called psyllid yellows in potato ( $\mathrm{Sol}$ anum tuberosum) and tomato (Solanum lycopersicum) (Fig. 4). This potentially devastating problem for tomato in the western United States (Al-Jabr, 1999) can be controlled using the following strategies: screening, tolerant cultivars including Yellow Pear (Liu and Trumble, 2004), sulfur 


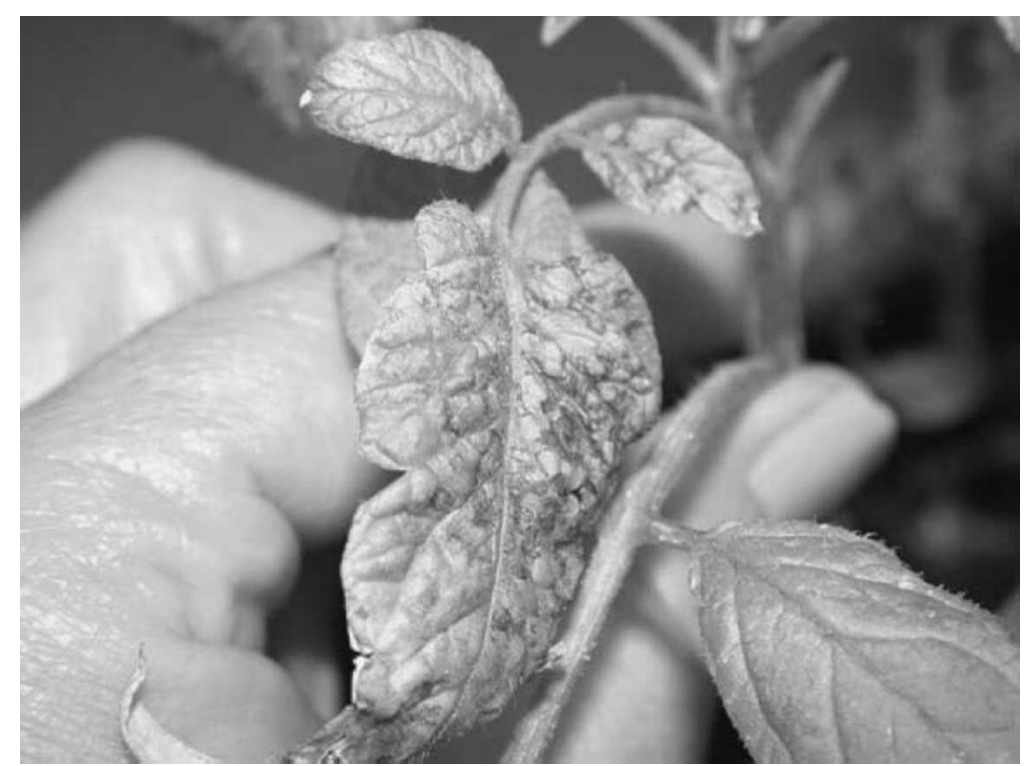

Fig. 2. Symptoms of tomato spotted wilt virus (TSWV) on tomato in outdoor production.

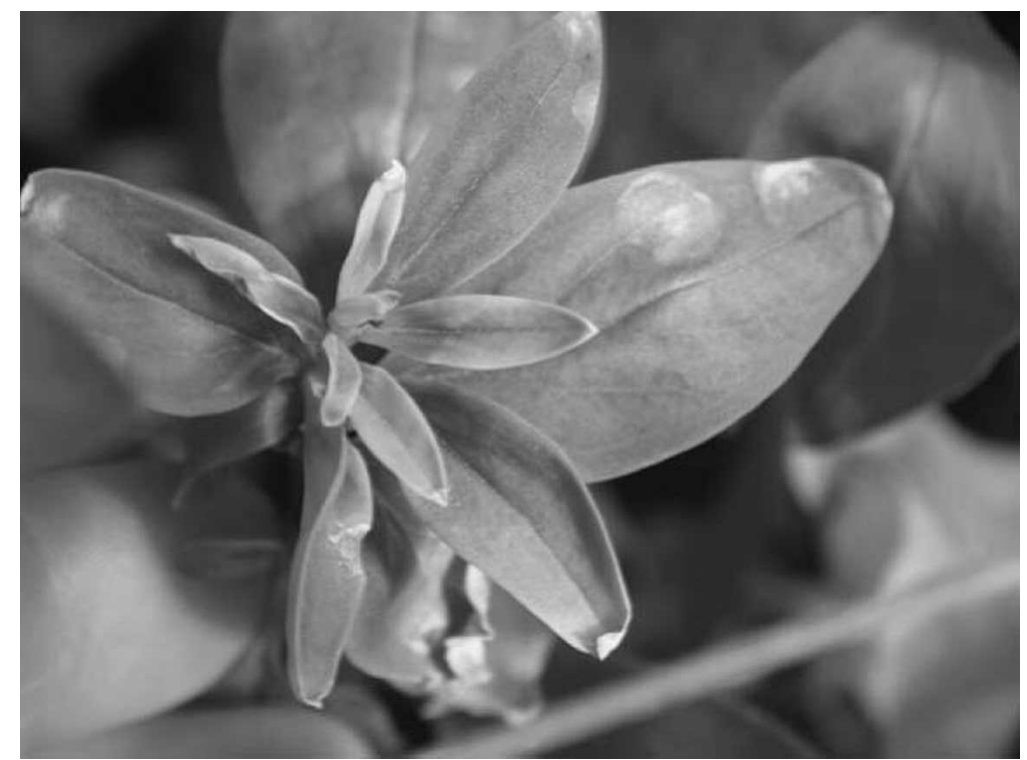

Fig. 3. Symptoms of impatiens necrotic spot virus (INSV) on snapdragon (Antirrbinum majus).

dust application, and biological control with Tamarixia spp., a commercially available parasitic wasp (Paine and Driestadt, 2007).

Various caterpillars (Lepidoptera) can cause damage on a wide variety of crops grown in a high tunnel. Fortunately, management of caterpillars is not difficult if caught early. Therefore, regular monitoring is required and when combined with the following management strategies can provide successful control: screening; application of pesticides such as soaps, spinosad, and Bacillus thuringiensis; and biological control with parasitic wasps (Greer and Diver, 1999). Parasitic wasps include Trichograma spp., which attacks lepidopteran eggs, and Cotesia spp., which attacks larvae.

Aphids (Aphidoidea) are another insect pest in the order Homoptera. Feeding on plant fluids, they can also vector a number of plant viruses. If aphid-vectored viruses are of concern, then, as with thrips, biological control may not be an option because producers cannot tolerate the presence of virus disease. However, if virus transmission is not a concern, then integration of the following management strategies will be successful (Greer and Diver, 1999): screening, soaps, oils, and neem-based insecticides. Biological control organisms such as ladybird beetle (Coccinellidae), which work best when augmented or inundative releases are used (Obrycki, 1998), green lacewing (Chrysoperla spp.), the parasitoid Aphidius, and Aphidoletes, a predatory midge, can be introduced.

The warm, dry environment in high tunnels promotes rapid increase in two-spotted spider mite (Tetranychus urticae) populations. Spider mites require temperatures of at least $80^{\circ} \mathrm{F}$ and less than $50 \%$ relative humidity (White and Liburd, 2005). Monitor mites closely, because once established, outbreaks are quick to follow. The following management strategies are often successful. Utilize irrigation to raise humidity levels and potentially decrease spider mite populations. Two predatory mites are commonly available for spider mite control. Amblyseius californicus (synonym Neoseiulus) does extremely well in hot, dry high tunnels, while Phytoseilus persimilus does not (Henn et al., 2008). There is also a predatory midge on the market called Feltiella or Theridoplosis that will perform well in hot, dry environments preferred by spider mites (Osborne et al., 2008).

Finally, the fungal disease powdery mildew (Erisyphales) needs to be considered (Fig. 5). Like spider mite, powdery mildew does very well in dry environments (Belanger et al., 2002). The pathogen requires a dry leaf surface, but higher relative humidity.

There are several management strategies, but by far the most successful is to increase air circulation. In a greenhouse, this can be accomplished with the addition of horizontal air flow fans, but in a high tunnel, without electricity, this addition is not feasible. Consider the following management strategies to help combat powdery mildew: spacing plants to allow for improved air circulation, rolling up the sides of the high tunnel or opening tunnel ends to improve air movement, neem-based or bicarbonate pesticide materials, and biofungicides such as Ampelomyces quisqualis or Bacillus subtilis (Shishkoff and McGrath, 2002) (Table 1).

Crop production in high tunnels lends itself to a truly IPM approach. 


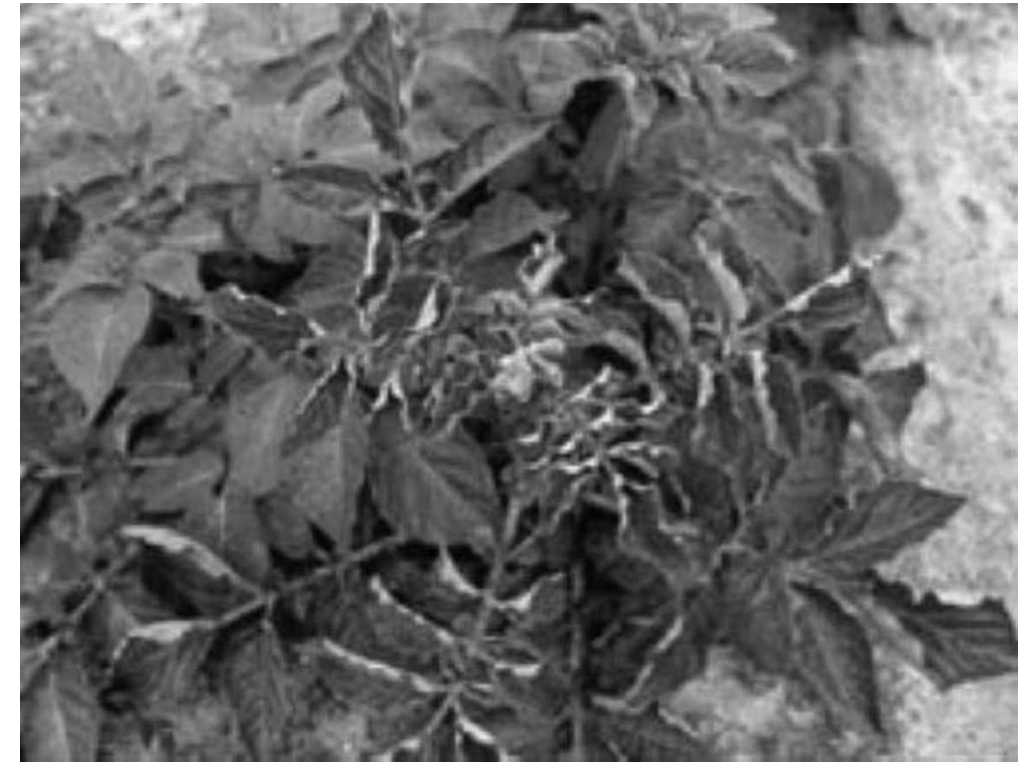

Fig. 4. Symptoms of psyllid yellows (photo: C. Wilson).

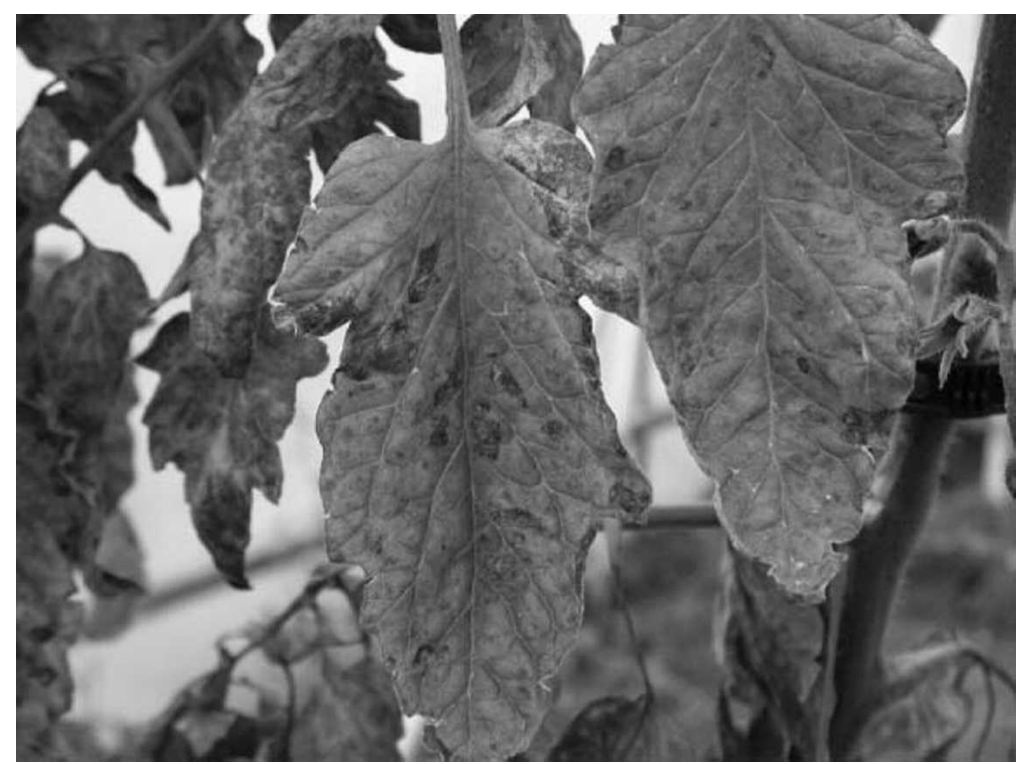

Fig. 5. Powdery mildew on tomato in a greenhouse.

Begin with clean soil, use crop rotation, employ resistant varieties, plan for proper plant spacing, and exclude pests with screening. Monitor closely for pests and diseases. When possible, release biological control organisms and/or encourage natural biological control populations with plant choices adjacent to the high tunnel. Last but not least, the judicious use of appropriate pesticides, many of which are labeled for the organic market and can be used in conjunction with biological controls, will complete a true integration of pest management strategies. Few cropping systems lend high tunnels do.

\section{Literature cited} State Univ., Ft. Collins, PhD Diss. Res. 71:213-220.
Belanger, R., W.R. Bushnell, A.J. Dik, and T.L.W. Carver (eds.). 2002. The powdery mildews: A comprehensive treatise. APS Press, St. Paul, MN.

Bessin, R., L.H. Townsend, and R.G. Anderson. 1993. Greenhouse insect management. Univ. Kentucky College Agr. Coop. Ext. Serv. Bul. ENT-60. 17 Sept. 2008. <www.ca.uky.edu/agc/pubs/ ent/ent60/ent60.pdfs.

Bethke, J.A. and T.D. Paine. 1991. Screen hole size and barriers for exclusion of insect pests of glasshouse crops. J. Entomol. Sci. 26:169-177.

Bethke, J.A., R.A. Redak, and T.D. Paine. 1994. Screens deny specific pests entry to greenhouses. Calif. Agr. 48(3): $37-40$.

Ellmore, C., J. Stapleton, C. Bell, and J. DeVay. 1997. Soil solarization: A nonpesticidal method for controlling diseases, nematodes, and weeds. Univ. California Div. Agr. Natural Resources Publ. 21377.

Gill, S. and J. Sanderson. 1998. Ball identification guide to greenhouse pests and beneficials. Ball Publishing, Batavia, IL.

Greer, L. and S. Diver. 1999. Integrated pest management for greenhouse crops. ATTRA-Natl. Sustainable Agr. Info. Serv. Publ. IP144. 17 Sept. 2008. $<$ http://attra.ncat.org/attra-pub/gh-ipm. html\#general/>.

Henn, T., R. Weinzierl, and P.G. Koehler. 2008. Beneficial insects and mites. 17 Sept. 2008. <http://edis.ifas.ufl.edu/IN078> .

Katan, J., A. Grinstein, A. Greenberger, O. Yarden, and J.E. DeVay. 1987. First decade (1976-1986) of soil solarization (solar heating): A chronological bibliography. Phytoparasitica 15:229-255.

Liu, D. and J.T. Trumble. 2004. Tomato psyllid behavioral responses to tomato plant lines and interactions of plant lines with insecticides. J. Econ. Entomol. 97:1078-1085.

themselves economically to this type of marriage of strategies as well as

Al-Jabr, M.A. 1999. Integrated pest management of tomato/potato psyllid, Paratrioza cockerelli (Sulc) (Homoptera: Psyllidae) with emphasis on its importance in greenhouse grown tomatoes. Colorado

Antignus, Y. 2000. Manipulation of wavelength-dependent behaviour of insects: An IPM tool to impede insects and restrict epidemics of insect-borne viruses. Virus
McSpadden Gardener, B.B. and D.R. Fravel. 2002. Biological control of plant pathogens: Research, commercialization, and application in the USA. Online Plant Health Prog. 17 Sept. 2008. <http:// dx.doi.org/doi:10.1094/PHP-20020510-01-RV>.

Moore, S. 2007. Ecological insect management in high tunnels. In: T. Blomgren and T. Frish (eds.). High tunnels. 17 Sept. 2008. <http://www.uvm.edu/sustainable agriculture/HighTunnels_PestManagement. pdf>.

Obrycki, J. 1998. Predacious Coccinellidae in biological control. Annu. Rev. Entomol. 43:295-321. 
Osborne, R.S., N.C. Leppla, and L.S. Osborne. 2008. Predatory gall midge (unofficial common name), Feltiella acarisuga (Vallot). 17 Sept. 2008. <http:// edis.ifas.ufl.edu/IN549>.

Paine, T.D. and S.H. Driestadt. 2007. Psyllids. Univ. California Agr. Natural Resources Publ. 7423. 17 Sept. 2008. <http://www.ipm.ucdavis.edu/PMG/ PESTNOTES/pn7423.html>.

Shishkoff, N. and M.T. McGrath. 2002. AQ10 biofungicide combined with chemical fungicides or AddQ spray adjuvant for control of cucurbit powdery mildew in detached leaf culture. Plant Dis. 86:915918.

Smith, T.M. 2003. A review of western flower thrips and tospoviruses. 17 Sept. 2008. <http://www.umass.edu/umext/ floriculture/fact_sheets/pest_management/ wft_03.html>.

Thomas, C. and E. Rajotte (eds.). 2004. Greenhouse IPM with an emphasis on biocontrols. 17 Sept. 2008. <http://resources. cas.psu.edu/ipm/ghmanual.pdf>.

Weeden, C.R., A.M. Shelton, and M.P. Hoffman. 2002. Orius tristicolor and $O$. insidiosus. Biological control: A guide to natural enemies in North America. 17 Sept. 2008. <http://www.nysaes.cornell.edu/ ent/biocontrol/predators/orius.html>.

White, J.C. and O.E. Liburd. 2005. Effects of soil moisture and temperature on the production and development of two spotted spider mite (Acari: Tetranychidae) in strawberries. J. Econ. Entomol. 98:154-158.

Zitter, T. 2008. Diseases are what you make them. 17 Sept. 2008. <http:// vegetablemdonline.ppath.cornell.edu/ NewsArticles/HighTunn.htm>. 